\title{
Specifying Learners' Professional Needs in Academic Writing
}

Original article

DOI: $10.31992 / 0869-3617-2021-30-12-102-109$

Chuikova Elina S. - Cand. Sci. (Education), Assoc. Prof., ORCID: 0000-0001-5136-8364, ResearcherID: I-1364-2014, chuikova_elina@mail.ru

Moscow City University (Samara Branch), Samara, Russia

Address: Stara Zagora str., 76, Samara, 443081, Russian Federation

Abstract. The article examines the controversial procedure of analyzing the learner's professional needs. Needs analysis is generally regarded as an invaluable tool for constructing a course syllabus. It might be really informative if the target situation analysis and present situation analysis are combined. Speaking about academic writing teaching for Russian non-academic students at the Bachelor Degree level, one should admit that students have no or limited experience of functioning in an academic area in English. Consequently, their responses to the questionnaires as one of the frequently used methods of target situation analysis are merely assumptions; and the answers could not be taken as objective and valid. The author presents a system of analyzing students' needs within the framework of Academic Writing course: namely, distinguishes the stages that precede or follow teacher-student talks about their expectations, provides more objective practice of examining learners' needs, and discusses ways of improving question-answer sessions/ interviews. Needs analysis practice that develops learners' professional needs involves task-based learning, reflexive activities, and teaching to ask good questions. Bringing into life the analogy between customer development theory in management and needs analysis practice in education, it is possible to work out a fruitful strategy. Conducting needs analysis pertains equally to specifying and developing students' needs in academic communication.

Keywords: academic writing, learner's professional needs, task-based needs analysis, reflexive practice, question sessions

Cite as: Chuikova, E.S. (2021). Specifying Learners' Professional Needs in Academic Writing. Vysshee obrazovanie $v$ Rossii = Higher Education in Russia. Vol. 30, no. 12, pp. 102-109, doi: 10.31992/0869-3617-2021-30-12-102-109 (In Russ., abstract in Eng.).

\section{Формирование профессиональных мотивов в изучении академического письма}

Научная статья

DOI: 10.31992/0869-3617-2021-30-12-102-109 
Чуйкова Элина Сергеевна - канд. пед. наук, доцент, ORCID: 0000-0001-5136-8364, ResearcherID: I-1364-2014, chuikova_elina@mail.ru

Московский городской педагогический университет (Самарский филиал), Самара, Россия Aдрес: 443081, г. Самара, ул. Стара Загора, 76

Аннотачия. Статья посвящена изучению профессиональньх мотивов обучаюшихся $b$ области академического письма. Определение профессиональных мотивов является обязательным этапом при конструировании курса обучения. Особенно действенна процедура, $b$ которой сбалансированы анализ ожиданий обучающихся и учёт уровня владения иноязычной письменной компетениией на начало курса. Специфичность ситуачии в российском высшем образовании заключается в тол, что студенты бакалавриата не имеют представления о сферах функиионирования академического английского языка. Как результат, прочедура анкетирования как наиболее частотный метод для определения ожиданий обучающихся не является объективным и валидным средством для оченки ситуаиии. Автор предлагает другую систему действий для анализа и развития у студентов понимания перспектив использования академического письла. Ао и после интервью преподавателя с обучающимися разрабатььваются задания проблемного типа, выполняя которые студенты лучше осознают сферу применения знаний и умений в области англоязвюного академического письма, ито позволяет организовать более объективную вопросно-ответную сессию. К эффективным средствам определения профессиональных мотивов студентов относятся проблемные задания, рефлексивные практики и задания на построение конкретизируюших вопросов. В статье проводится аналогия между прочедурой качественного интервью с клиентами В бизнесе и прочедурой анализа мотивов обучаюоиихся, в которой тоже можно воспользоватьса продуктивныли средствами опроса. Автор приходит к выводу, что сама прочедура выявления мотивов обучающихся одновременно полезна и для обучающихся, т.к. позволяет формировать и уточнять их профессиональные мотивы.

Ключевые слова: академическое письмо, профессиональные мотивь обучаюшихся, проблемные задания, рефлексивные задания, интервьюирование обучающихся

Аля иитирования:Chuikova E.S. Specifying Learners' Professional Needs in Academic Writing // Высшее образование в России. 2021. Т. 30. № 12. С. 102-109. DOI: 10.31992/0869-3617-202130-12-102-109

\section{Introduction}

The design of any teaching course requires a thorough and deliberate choice of its aims, outcomes, content, methods of teaching and the scope of other important practical teaching details. It is a worldwide practice to involve both sides of a teaching process into setting the goals that would suit students' real needs. Needs analysis is the initial step in curriculum design; and its primary aim is to examine and support learning needs [1-3] while planning the course content and further implementing class activities. A proper procedure may result in a more 'focused course' [4]. However 'self-defined learn- ing needs' are sometimes misleading and should be backed up with experts' analysis [2; 5]. The reason is that students' experience in the use of English for academic purposes (EAP) is different in Bachelor, Master's degrees and $\mathrm{PhD}$ levels. Bachelor students differ in their needs concerning their language level. 'Low-level students expressed stronger pragmatic learning needs and high-level students expressed noticeable interests in understanding a professor's... implied meaning' [6]. It should be noted that Master's degree students confess that 'it is too late to start learning English from scratch at MA' [7] stating the problem that professional needs should be 
Outcomes of the activities designed to analyze students' needs

\begin{tabular}{|c|l|}
\hline \multicolumn{1}{|c|}{ What activities provide a teacher with } & \multicolumn{1}{c|}{ What activities provide a student with } \\
\hline - the assessment of students' language proficiency and & - thinking of new career opportunities; \\
measuring their academic text authenticity; & - constructing an unexpected learning path; \\
- the explicit and implicit ways to introduce to students the & - developing one's conscious thinking of academic writing \\
functions and possible application spheres of academic & $\begin{array}{l}\text { and deepening the knowledge of EAP potential applica- } \\
\text { writing. }\end{array}$ \\
& tions; \\
& - meaningful choice of writing instructor career path. \\
\hline
\end{tabular}

developed at an early stage when these needs are not realized yet. As for $\mathrm{PhD}$ students who are better aware of challenges in EAP acquisition, they reveal the predictable expectations in support building and genre conventions [5].

The procedure of needs analysis varies. It is generally accepted that Target Situation Analysis and Present Situation Analysis combined may provide an objective picture of students' real demands. The procedure of Target Situation Analysis involves a range of questions on students' target needs in communication [8]. For instance, during academic writing, the focus will be on the potential communicative skills that students may use in the academic sphere. Present Situation Analysis involves data thoroughly collected by a tutor on the basis of students' work/text/speech analysis. In Present Situation Analysis students' answers to the direct questions that involve self-analysis are coupled with the experts' task-based analysis. In various needs analysis procedures, tutors deal with students assumptions. Though the process should be interactive, the problem of a proper identification of learners' needs emerges. It is not always obvious to what extent students possess sufficient knowledge to make valid assumptions which language teachers may further implement into the course design and curriculum change. As a result, researchers continue to test and examine new techniques that 'can improve the reliability and validity of NA (needs analysis) practice' [9].

This study aims to answer two research questions:

1. Can Present Situation Analysis and Target Situation Analysis be both applied at the initial stage of teaching academic writing?
2. Can activities aimed at specifying students' needs also develop their awareness of their potential needs?

\section{Methods}

In academic context, the main foci in assessing writing are validity and reliability, feedback, and testing performance [10]. To tackle the problem of validity and reliability in the process of studying students' needs, we applied qualitative and quantitative methods. They include students' interviews, questionnaire surveys, taskbased assessment of language proficiency and reflexive practice.

The research has been based on the bachelor degree students' performance. Approximately 90 students have been involved in the procedure. They have been students taking Academic Writing course at Samara branch of Moscow City University within the last three years. Over the course, we have implemented several reflexive activities that contribute to teaching as well as to learning practice. The report written at the end of the course has indicated additional outcomes that students named analyzing the reflexive activities they have tried.

The students have been given several opportunities for self-assessment of their academic writing skills and potential application of their knowledge. The activities chosen for the students have all been designed by the writing instructor, and the materials have been created either by the students of this academic year or by the students of the previous year. The procedure was as follows:

1. Before the course, the students answered the questions in the Pre-course Self-Assessment list (questionnaire surveys). 
2. At the beginning of the course, the students tried to assess the academic text of another student working out their assessment criteria (task-based assessment).

3. The first paragraph answered the question 'Why do I need an academic writing course?' (reflexive activity coupled with task-based assessment).

4. At the appropriate point of every module (after learning the requirements for a particular academic text), the writing instructor provided students with guidelines to assess their first drafts. The activity could be organized as self- or peer correction (reflexive practice coupled with task-based assessment).

5. The instructor then provided a Group Error List for students to identify the mistakes and to practise correction (reflexive practice).

6. At the end of the course, the students extended the list of questions they got in a Precourse Self-Assessment session. They specified the questions, developed good questions based on the scope of knowledge they got within the course (questionnaire surveys).

7. Teacher-student session was hold to specify the challenges that students had, both common and individual ones (students' interviews).

To illustrate the procedure of developing and specifying students' needs, examples of the mentioned activities are presented further.

\section{Interviews, questionnaire surveys}

Interaction with students is an empirical way to examine students' needs. Analysis of students' needs is an essential part in the development of marketing strategies in higher institutions, where students are considered customers [11-13]. Being well-known tools in customer development theory, interviews and questionnaires work well in the educational context if we follow customer development recommendations for asking 'good questions' [14]:

- The extensive use of 'how', 'why', 'when' questions extends students' boundaries in a writer-reader interaction and leads to a better comprehension.
- Avoiding the question implying subjective assumptions ('Will you use...?') and replacing them by a more demanding 'Do you manage to use ... right now?' places our students into situational learning, developing the urgently required skills.

- The key questions such as 'If you do not learn it now, what will you miss?' bring up our students as conscious people, raise their awareness of what they personally acquire now for a potential well-being in this sphere.

In the Pre-course Self-Assessment session, students asked mostly general questions. On completion of the course, they went into the same set of questions and suggested improvements specifying them.

For example, the assignment is to specify the questions in the list.

Original questions: Do you know the distinction between 'study'/'academic'/"profession al' language? Can you use English effectively as an academic language?

Students' revised options: What is the difference between academic and professional writing? Are you able to write a report right now? What projects can you participate in after an academic writing course?

Original question: Do you use any strategies when you revise your writing assignments?

Students' options: How many strategies can you use for revision? Do you involve other people in reviewing? How often do you submit your first draft to your teacher straight after writing? Where can you find the criteria for the revision of your paragraph/essay/report?

Original question: Can you identify the components of an effective abstract in English: background, objective, methods, results, and findings?

Students' options: What components can you find in an abstract in English? How do we name them? How would you start writing an abstract?

Original question: Do you know how to transform a written academic text into a verbal presentation in an easy and efficient way?

Students' options: If you are asked to prepare a verbal presentation now, will you write the 
text before you start presenting? What elements are in common in an academic text and in an oral presentation? How many parts are there in an oral presentation? What are the typical phrases we use to indicate a swift move from one part to another? Do we use them in writing?

Original question: Do you know digital tools that assist in checking and correcting academic texts in English?

Students' options: What digital tools do you use to check a text in English? What digital tools do you recommend to check academic texts in English? How often do you apply them?

The practice of going over the questionnaire has highlighted a deeper students' understanding of numerous requirements to different genres, tools for correction, possible spheres of application of their knowledge, activities to use at different stages of the writing process, etc. Students have named the details that they acquired while building good questions, i.e., more focused questions.

\section{Task-based assessment}

The next valuable tool for students' needs analysis is giving challenging tasks. 'The degree to which students benefit from the tasks differs according to their proficiency levels' [15]. The degree to which writing instructors benefit from the tasks correlates with the level of student critical thinking, whether they are ready to question the assignment, to search for additional information before going into it.

For example, assignment 1: Read the model academic text. Try to assess it.

If students start immediately to do the task, the instructor receives a picture of the students' previous knowledge of the assessment criteria. There might be not numerous criteria; still they indicate what requirements for writing formal texts students are ready to follow.

Students with a more critical mindset start asking questions, as they are not satisfied with the initial parameters of the assignment. They are not aware of all task requirements to complete it successfully. If at least two or three students come up with their questions to clarify the task, the whole group would benefit from them. If there are none, writing instructors are welcome to suggest their ideas in an implicit form: What additional material do you need besides the text to be able to assess it as an expert? What knowledge is required to read and analyze academic texts? Do you possess it?

When the whole group realizes the gap between their knowledge and the required result of the task, it might be useful to provide some sources to search for additional information that could bring students to the parameters they should keep in mind while reading and writing academic texts at this stage of the course.

For example, Academic writing is used to communicate in a specific sphere through specific text genres. Watch the interview with Martin Hewings - Academic English: How Is It Different? and the key note speech by Prof. David Crystal Academic English - Prof. David Crystal on standard vs. non-standard English. Write down the characteristics of academic writing that both speakers mention in their presentations. Turn back to the academic text of the task. Find these characteristics in the text.

For example, assignment 2: Now you will define the phenomenon of Academic English. Read the extracts (1-7) below. Compile your definition of Academic English. Try to make it as complete as possible. While combining the material, do not forget about plagiarism: paraphrase and make references.

The assignment may seem less challenging to students. However, it anticipates a new theme: Learning strategies to avoid plagiarism. Thus, it tests students' needs in a new area again.

Task-based assessment may be effectively used as an introduction to a new theme being formative in nature. Moreover, sometimes task-based assessment may be used as a summative tool to sum up students' knowledge of the topic.

For example, analyze two versions of a paragraph. Which one would you consider a better version for publishing in some academic source? Why? 
The criteria for assessment may vary every time, as an instructor may cover a new aspect of writing before giving the same task, changing the model text rather than an assignment.

\section{Reflexive practice}

By reflexive practice we mean an extensive use of checklists, guidelines, self-assessment lists, group errors lists. Over the course students' performance was guided through reflexive practice arranged on their first and second drafts. To illustrate the idea of reflexive practice, examples of a checklist, a guideline, a self-assessment list, and a group error list are provided.

For example, analyze two versions of a paragraph. Which one would you consider a better version for publishing in some academic source?

Checklist. Criteria for comparison:

- topicality;

- original thesis statement;

- original arguments;

- original/catchy title;

- original/promising introduction/conclusion;

- dialogue of different viewpoints, which indicates the author's professional outlook;

- perspectives for further research are mentioned.

For example, use the assignment in activity $N$ and the students' essays to answer the questions that follow.

Guideline

Do the essays address the assignment task? Why or why not?

Essay 1

Essay 2

2. What does each writer do well?

Essay 1

Essay 2

3. What techniques does each writer use in the introduction? conclusion?

Essay 1

Essay 2

4. What does each writer need to do to improve the essay?

Essay 1

Essay 2
For example, Expository Paragraph Checklist (self-assessment checklist).

Check off the items that are true. If some of the items are not checked off, correct your paragraph. If you need an explanation of any of the terms, review the chapter.

1. My paragraph answers directly to the question in the topic sentence.

2. The paragraph has just one main idea.

3. There is a topic sentence which has a topic and a controlling idea.

4. The topic sentence is supported.

5. Nouns and pronouns are used appropriately.

6. Linking words are used properly and do not disturb the reader's attention.

7. The paragraph layout (i.e., structure) is correct.

For example, Group error list.

Identifying Students' Typical Errors in Style and Correcting Them

Activity 1. Read a collection of unqualified statements from students' works. Use tentative language to change the tone and not to sound like a person who labels people and things and who feels that he knows all about something in all its forms for all time. Change other elements of informal style into formal ones.

1. We often write these types of texts, but nobody thinks about errors, about grammatical structures.

2. Reading fiction books is crucial in everybody's life.

3. It is considered that the gap between the rich and the poor is increasing; actually, it is not true...

Activity 2. Read the sentences and correct any misuse of pronouns to meet the requirements of formal writing. If there are other errors in style, suggest your improvements.

1. To be a good writer, first of all, you should master special techniques and essential skills.

2. Also formulating and structuring the idea expects accuracy from you.

3. People are normally active, but when you smoke, your lungs are so damaged that it's hard to run and play sports... 


\section{Results and Discussion}

Increasingly students point out that they have found new career opportunities while taking the academic writing course. The percentage of students who feel ready to help others in the academic environment - either by translating or writing academic texts in English or by becoming writing instructors - raises from $8 \%$ to $35 \%$ within the last three years. The mission of my course is to specify and develop learners' professional needs in academic writing. This way it is possible to raise writing instructors in academia, because interest in being a teaching instructor may be one of the other possible needs.

The reflexive activities have been successfully tested in Samara branch of Moscow City University. A set of working tools has been implemented in the academic writing course: namely, tasks for organizing task-based learning, reflexive topics for texts to write, activities focused on teaching to ask specific questions to try with students, a questionnaire to learn about students' needs. 'As a scientist, you are fully capable of doing research, gathering data... If you are polite and creative, people will be more receptive to you than you might think" [14].

Thus, after testing reflexive activities, the research answers positively its main questions. Present Situation Analysis and Target Situation Analysis may be both applied at the initial stage of teaching academic writing to non-academic students. They provide a more objective view on students' real needs and gaps. Moreover, a balanced analysis allows to specify students' needs as well as to develop their awareness of their potential needs. It is hard to say whether academic writing perspectives could have been equally successfully brought to students' minds without turning to the authorities. Task-based assessment has been generally followed by reading excerpts from the articles of Russian scholars on academic writing issues in Russia [16-18].

\section{Conclusion}

The perception of the needs analysis procedure mainly as a tool for learning and specify- ing someone's needs, limits our possibilities in an educational context. Interviewing students may provoke their thinking of new career opportunities, construct an unexpected learning path, develop one's conscious thinking of academic writing, and deepen the knowledge of EAP potential applications. Sincere desire to provide students with nuances in the academic writing sphere, to boost their microwriting skills in a meaningful way, leads writing instructors to a revolutionary idea: a properly designed and applied needs analysis may develop our students in the academic area. We unlock for them new ways of academic writing application through constant interaction and flexible guidance.

The extensive use of reflexive practice brings a better interaction in class. After all, a constructive dialogue, which is implied by an effective needs analysis procedure, forms a channel between an instructor and the students. Through this channel one could gain more educational specialist forming implicit effects than straightforward information sharing. The role of professional needs analysis in academic writing teaching cannot be overestimated. This brings the writing instructor with another challenge: to share tacit knowledge with students, one should be in the know of current trends in the academic writing areas.

\section{References}

1. Brown, J.D. (2009). Foreign and Second Language Needs Analysis. In: Long, M.H., Doughty, C.J (Eds.). Handbook of Language Teaching. Oxford: Wiley-Blackwell, pp. 269-293

2. Hyland, K. (2010). Second Language Writing. Cambridge University Press, doi: https://doi. org/10.1017/CBO9780511667251

3. Ulum, O.G. (2015). A Needs Analysis Study for Preparatory Class ELT Students. European Journal of English Language Teaching. Vol. 1, no. 1, pp. 14-29, doi: http://dx.doi.org/10.46827/ejel. v0i0.78

4. Chostelidou, D. (2010). A Needs Analysis Approach to ESP Syllabus Design in Greek Tertiary Education: A Descriptive Account of Students' Needs. Procedia - Social and Bebavioral Sciences. Vol. 2, no. 2, pp. 4507-4512, doi: 10.1016/j. sbspro.2010.03.721 
5. Shen, L., Carter, S., Zhang, L.J. (2019). EL1 and EL2 Doctoral Students' Experience in Writing the Discussion Section: A Needs Analysis. Journal of English for Academic Purposes. Vol. 40, pp. 74-86, doi: https://doi.org/10.1016/j. jeap.2019.06.004

6. Youn, S.J. (2018). Task-based Needs Analysis of L2 Pragmatics in an EAP Context. Journal of English for Academic Purposes. Vol. 36, pp. 86-98, doi: https://doi.org/10.1016/j.jeap.2018.10.005

7. Akbari, Z. (2016). The Study of EFL Students' Perceptions of Their Problems, Needs and Concerns over Learning English: The Case of MA Paramedical Students, Procedia-Social and Behavioral Sciences. Vol. 232, pp. 24-34, doi: https://doi.org/10.1016/j.sbspro.2016.10.006

8. Li, J. (2014). Needs Analysis: An Effective Way in Business English Curriculum Design. Theory and Practice in Language Studies. Vol. 4, no. 9, pp. 1869-1874, doi: https://doi.org/10.4304/ tpls.4.9.1869-1874

9. Serafini, E.J., Lake, J.B., Long, M.H. (2015). Needs Analysis for Specialized Learner Populations: Essential Methodological Improvements. English for Specific Purposes. Vol. 40, pp. 11-26, doi: https://doi.org/10.1016/j. esp.2015.05.002

10. Zheng, Y., Yu, S. (2019). What Has Been Assessed in Writing and How? Empirical Evidence from Assessing Writing (2000-2018). Assessing Writing. Vol. 42, article no. 100421, doi: https://doi. org/10.1016/j.asw.2019.100421

11. Roy, R. (2019). 360 Degree View of Metrics for the Consumers, Creators, and Customers. In: Performance Improvement: Towards the Development of the Field. Available at: https:// www.dropbox.com/s/bk2o $7 \mathrm{~m} 3 \mathrm{wr} 7 \mathrm{zu} 3 \mathrm{yd} /$ PerformanceXpress\%20July\%202019\%20-\%20 EDITOR $\% 27 S \% 20$ PICK $\% 20 J U L Y \% 202019 \% 20$ $360 \% 20$ Degree $\% 20$ View $\% 20$ of $\% 20$ Metrics $\% 20$ for $\% 20$ the $\% 20$ Consumers $\% 2 \mathrm{C} \% 20$ Creators $\%$ 2C $\% 20$ and $\% 20$ Customers.docx? $\mathrm{dl}=0 \#$ (accessed 08.11.2021).

12. Guilbault, M. (2018). Students as Customers in Higher Education: The (Controversial) Debate Needs to End. Journal of Retailing and Consumer Services. Vol. 40, pp. 295-298, doi: https://doi. org/10.1016/j.jretconser.2017.03.006

13. Yanova, N. (2015). Assessment of Satisfaction with the Quality of Education: Customer Satisfaction Index. Procedia - Social and Behavioral Sciences. Vol. 182, pp. 566-573, doi: https://doi. org/10.1016/j.sbspro.2015.04.782

14. Constable, G. (2014). Talking to Humans: Success Starts with Understanding Your Customers. Giff Constable, 88 p. ISBN 099080092X

15. Yasuda, S. (2015). Exploring Changes in FL Writers' Meaning-Making Choices in Summary Writing: A Systemic Functional Approach. Journal of Second Language Writing. Vol. 27, pp. 105-121, doi: https://doi.org/10.1016/j.jslw.2014.09.008

16. Korotkina, I.B. (2017). On "Road Maps", the 'Ranking Rush" and Academic Writing. Vysshee obrazovanie $v$ Rossii = Higher Education in Russia. No. 208 (1), pp. 15-24. (In Russ., abstract in Eng.).

17. Safonova, M.A., Safonov, A.A. (2021). Transformation of Academic Writing in the Digital Age. Vysshee obazovanie $v$ Rossii $=$ Higher Education in Russia. Vol. 30, no. 2, pp. 144-153, doi: 10.31992/0869-3617-2021-30-2-144-153. (In Russ., abstract in Eng.).

18. Shpit, E.I., Kurovskiy, V.N. (2020). Academic Writing in English in the Structure of Higher Education in Russia. Vysshee obrazovanie $v$ Rossii = Higher Education in Russia. Vol. 29, no. 2, pp. 83-91. (In Russ., abstract in Eng.).

The paper was submitted 05.11.21 Accepted for publication 26.11.21 